Proc. Indian Acad. Sci. (Chem. Sci.), Vol. 99, No. 4, October 1987, pp. 209-215.

(C) Printed in India.

\title{
Catalytic decomposition of hydrogen peroxide on fine particle ferrites and cobaltites
}

\author{
TANU MIMANI, P RAVINDRANATHAN and K C PATIL* \\ Department of Inorganic and Physical Chemistry, Indian Institute of Science, Bangalore \\ 560012 , India
}

MS received 10 April 1987; revised 23 June 1987

\begin{abstract}
The kinetics of heterogeneous decomposition of hydrogen peroxide on fine particle ferrites, $\mathrm{MFe}_{2} \mathrm{O}_{4}$ and cobaltites, $\mathrm{MCO}_{2} \mathrm{O}_{4}$, where $\mathrm{M}=\mathrm{Mn}, \mathrm{Fe}, \mathrm{Co}, \mathrm{Ni}, \mathrm{Zn}$ and $\mathrm{Mg}$, have been investigated. The decomposition of $\mathrm{H}_{2} \mathrm{O}_{2}$ was found to be first order at low concentration $(0.3 \%)$ and zero order at high concentration $(30 \%)$ of $\mathrm{H}_{2} \mathrm{O}_{2}$. The catalytic activity of cobaltites on the decomposition of $\mathrm{H}_{2} \mathrm{O}_{2}$ is found to be better than ferrites. The observed catalytic behaviour of ferrites and cobaltites has been attributed to their fine particle nature, large surface area and electronic structure.
\end{abstract}

Keywords. Hydrogen peroxide decomposition kinetics; ferrites; cobaltites.

\section{Introduction}

The kinetics of decomposition of hydrogen peroxide has been studied by a large number of workers (Schumb et al 1955). The interest in the kinetics of $\mathrm{H}_{2} \mathrm{O}_{2}$ decomposition stems from its use in oxygen production, power generation and electrolytic reduction of oxygen in which $\mathrm{H}_{2} \mathrm{O}_{2}$ is an intermediate. The choice of a suitable catalyst for the decomposition of $\mathrm{H}_{2} \mathrm{O}_{2}$ has proved to be difficult due to the high cost of catalysts like silver oxide, platinum and palladium black as well as the poor reactivity of cheap catalysts like $\mathrm{MnO}_{2}, \mathrm{Co}_{2} \mathrm{O}_{3}, \mathrm{Fe}_{2} \mathrm{O}_{3}$ etc. Recently, Onuchukwu (1984), Goldstein and Tseung (1974) and Cota et al (1964) have reported that ferrites; cobalt-iron oxide spinels $\left(\mathrm{Co}_{x} \mathrm{Fe}_{3-x} \mathrm{O}_{4}, x=0-3\right)$ in particular, show high activity in the decomposition of $\mathrm{H}_{2} \mathrm{O}_{2}$. The catalytic activity of these oxides has been attributed to their electronic structure, composition, surface morphology and microstructure (surface area).

It is rather surprising that although Co-Fe oxide spinels have been investigated in great detail there is only one report (Tarasevich and Efremov 1980) on the use of cobaltites, $\mathrm{MCO}_{2} \mathrm{O}_{4}$, where $\mathrm{M}=" \mathrm{Mn}, \mathrm{Co}, \mathrm{Ni}$ and $\mathrm{Mg}$, as catalysts for the decomposition of $\mathrm{H}_{2} \mathrm{O}_{2}$. It has been observed that $\mathrm{NiCo}_{2} \mathrm{O}_{4}$ dispersed over carbon black exhibits maximum activity for $\mathrm{H}_{2} \mathrm{O}_{2}$ decomposition and catalytic activity is attributed to the increased dispersedness of cobaltites on carbon black. Therefore, it was considered interesting to study the heterogeneous decomposition of $\mathrm{H}_{2} \mathrm{O}_{2}$ in the presence of fine particle ferrites, $\mathrm{MFe}_{2} \mathrm{O}_{4}$, and cobaltites, $\mathrm{MCo}_{2} \mathrm{O}_{4}$, where

*To whom all correspondence should be addressed 
$\mathrm{M}=\mathrm{Mn}, \mathrm{Fe}, \mathrm{Co}, \mathrm{Ni}, \mathrm{Zn}$ and $\mathrm{Mg}$. The choice of these catalysts is warranted by the fact that they have large surface areas $\left(12-140 \mathrm{~m}^{2} / \mathrm{g}\right)$ and are prepared by the low temperature decomposition of novel hydrazine precursors $\mathrm{N}_{2} \mathrm{H}_{5} \mathrm{M}_{1 / 3} \mathrm{M}_{2 / 3}^{\prime}$ $\left(\mathrm{N}_{2} \mathrm{H}_{3} \mathrm{COO}\right)_{3} \mathrm{H}_{2} \mathrm{O}, \mathrm{M}=\mathrm{Mn}, \mathrm{Fe}, \mathrm{Co}, \mathrm{Ni}, \mathrm{Zn}$ and $\mathrm{Mg} ; \mathrm{M}^{\prime}=\mathrm{Fe}$ or Co. The novelty of the precursors is their autocatalytic combustion behaviour, with the evolution of large amounts of gases, leaving behind fine particle oxides (Ravindranathan and Patil 1987; Ravindranathan et al 1987).

\section{Experimental}

\subsection{Preparation of the oxides}

The preparation and characterisation of hydrazine precursors to fine particle ferrites, $\mathrm{N}_{2} \mathrm{H}_{5} \mathrm{M}_{1 / 3} \mathrm{Fe}_{2 / 3}\left(\mathrm{~N}_{2} \mathrm{H}_{3} \mathrm{COO}\right)_{3} \mathrm{H}_{2} \mathrm{O}$ (Ravindranathan and Patil 1987) and cobaltites $\mathrm{N}_{2} \mathrm{H}_{5} \mathrm{M}_{1 / 3} \mathrm{Co}_{2 / 3}\left(\mathrm{~N}_{2} \mathrm{H}_{3} \mathrm{COO}\right)_{3} \mathrm{H}_{2} \mathrm{O}$ (Ravindranathan et al 1987), where $\mathrm{M}=\mathrm{Mn}, \mathrm{Fe}, \mathrm{Co}, \mathrm{Ni}, \mathrm{Zn}$ and $\mathrm{Mg}$, have already been described. Only the preparation of fine particle ferrites and cobaltites is described here.

Ferrites: The precursors $\mathrm{N}_{2} \mathrm{H}_{5} \mathrm{M}_{1 / 3} \mathrm{Fe}_{2 / 3}\left(\mathrm{~N}_{2} \mathrm{H}_{3} \mathrm{COO}\right)_{3} \mathrm{H}_{2} \mathrm{O}$ were ignited in a silica crucible and allowed to decompose autocatalytically in the absence of a flame or an external heat source. The crystals decompose with the evolution of $\mathrm{NH}_{3}, \mathrm{H}_{2} \mathrm{O}, \mathrm{N}_{2}$, $\mathrm{H}_{2}$, and $\mathrm{CO}_{2}$. The decomposition products, ferrites $\left(\mathrm{MFe}_{2} \mathrm{O}_{4}\right)$, are fine, voluminous residues.

Cobaltites: The precursors $\mathrm{N}_{2} \mathrm{H}_{5} \mathrm{M}_{1 / 3} \mathrm{Co}_{2 / 3}\left(\mathrm{~N}_{2} \mathrm{H}_{3} \mathrm{COO}\right)_{3} \mathrm{H}_{2} \mathrm{O}$ were ignited in a silica crucible and allowed to decompose autocatalytically as described above. The decomposition products, cobaltites $\left(\mathrm{MCO}_{2} \mathrm{O}_{4}\right)$, were also fine in nature.

Some important properties like XRD data, particle size, BET surface area (determined by $\mathrm{N}_{2}$ adsorption at liquid nitrogen temperature) of ferrites and cobaltites have been summarised in table 1.

Table 1. Some properties of fine particle ferrites and cobaltites.

\begin{tabular}{|c|c|c|c|c|c|}
\hline \multirow[b]{2}{*}{ Compound } & \multicolumn{2}{|c|}{ XRD data } & \multirow[b]{2}{*}{$\begin{array}{l}\text { Particle } \\
\text { density } \\
\left(\mathrm{g} / \mathrm{cm}^{3}\right)\end{array}$} & \multirow[b]{2}{*}{$\begin{array}{c}\text { Particle } \\
\text { size } \\
\text { (micron) }\end{array}$} & \multirow[b]{2}{*}{$\begin{array}{c}\text { Surface } \\
\text { area } \\
\left(\mathrm{m}^{2} / \mathrm{g}\right)\end{array}$} \\
\hline & $\begin{array}{c}a^{*} \\
(\mathrm{~nm})\end{array}$ & $\begin{array}{c}\text { Crystallite } \\
\text { size } \\
(\mathrm{nm})\end{array}$ & & & \\
\hline $\mathrm{MgFe}_{2} \mathrm{O}_{4}$ & 0.8388 & 13 & $4 \cdot 118$ & $3 \cdot 15$ & 114 \\
\hline $\mathrm{MnFe}_{2} \mathrm{O}_{4}$ & 0.8321 & 6 & $3 \cdot 269$ & 1.65 & 140 \\
\hline $\mathrm{CoFe}_{2} \mathrm{O}_{4}$ & 0.8418 & 10 & $3 \cdot 649$ & $2 \cdot 5$ & 116 \\
\hline $\mathrm{NiFe}_{2} \mathrm{O}_{4}$ & 0.8359 & 22 & 3.574 & $3 \cdot 2$ & 26 \\
\hline $\mathrm{ZnFe}_{2} \mathrm{O}_{4}$ & 0.8477 & 9 & $3 \cdot 437$ & $3 \cdot 4$ & 108 \\
\hline $\mathrm{MgCo}_{2} \mathrm{O}_{4}$ & 0.8130 & 10 & 3.0517 & $2 \cdot 20$ & 47 \\
\hline $\mathrm{MnCo}_{2} \mathrm{O}_{4}$ & 0.8113 & 24 & $5 \cdot 46$ & 0.82 & 24 \\
\hline $\mathrm{FeCO}_{2} \mathrm{O}_{4}$ & 0.8222 & $6 \cdot 5$ & $3 \cdot 919$ & $4 \cdot 35$ & 116 \\
\hline $\mathrm{NiCO}_{2} \mathrm{O}_{4}$ & 0.8118 & 10 & $5 \cdot 7$ & $\dot{-}$ & $12 \cdot 4$ \\
\hline $\mathrm{ZnCO}_{2} \mathrm{O}_{4}$ & 0.8172 & 14 & 5.06 & $4 \cdot 56$ & 65 \\
\hline
\end{tabular}

*Powder diffraction file, Inorganic vol-PDIS-10iRB, Joint Committee on Diffraction standards, Pennsylvania; 1967. 


\subsection{Kinetics of $\mathrm{H}_{2} \mathrm{O}_{2}$ decomposition}

Stabiliser free $\mathrm{H}_{2} \mathrm{O}_{2}$ (AnalaR $\mathrm{BDH}, 30 \% \mathrm{w} / \mathrm{v}$ ) solution was used in all the experiments. The solution was standardised by standard $\mathrm{KMnO}_{4}$ before the run. The kinetics of $\mathrm{H}_{2} \mathrm{O}_{2}$ decomposition was studied using $30 \%$ and $0.3 \%$ solutions. Precautions were taken to protect the solutions from light and heat during storage.

A schematic diagram of the experimental set-up used is shown in figure 1 . This is a slightly modified version of the gasometric method (Deren et al 1963). The catalyst is taken in the reaction vessel which is immersed in a thermostat. To the side limb of the reaction vessel is attached a ' $V$ ' shaped tube, well-protected from light, containing the $\mathrm{H}_{2} \mathrm{O}_{2}$ solution. The reaction rate is deduced in terms of the volume of oxygen evolved in the liquid phase. The oxygen evolved is measured with the help of the manometer filled with water coloured with potassium dichromate. As oxygen is collected in the manometer, the water level in the right arm lowers while it rises in the left. In a given interval of time the difference in water levels in the arms of the manometer, which is proportional to the amount of $\mathrm{O}_{2}$ evolved, can be determined by running down water from the burettes at the left. The large burette of $50 \mathrm{ml}$ capacity is used to drain off larger volumes while the smaller $10 \mathrm{ml}$ capacity is used to make minor corrections.

In a typical experiment, a few milligrams of the catalyst were placed in the reaction vessel and attached to the set-up. About $10 \mathrm{ml}$ of the $\mathrm{H}_{2} \mathrm{O}_{2}$ solution were poured into the ' $\mathrm{V}$ ' tube, which was attached to the reaction vessel. The reaction vessel and the ' $V$ ' tube were immersed in thermostat maintained at $30^{\circ} \mathrm{C} \pm 0.5^{\circ} \mathrm{C}$ and atmospheric pressure. The whole set-up was left undisturbed till the reaction vessel and the tube attained thermal equilibrium. During this time, $\mathrm{O}_{2}$ evolved due to self-decomposition of $\mathrm{H}_{2} \mathrm{O}_{2}$, was adjusted by bringing the manometric liquid to the initial level before the start of the run. After equilibrium the $\mathrm{H}_{2} \mathrm{O}_{2}$ solution was

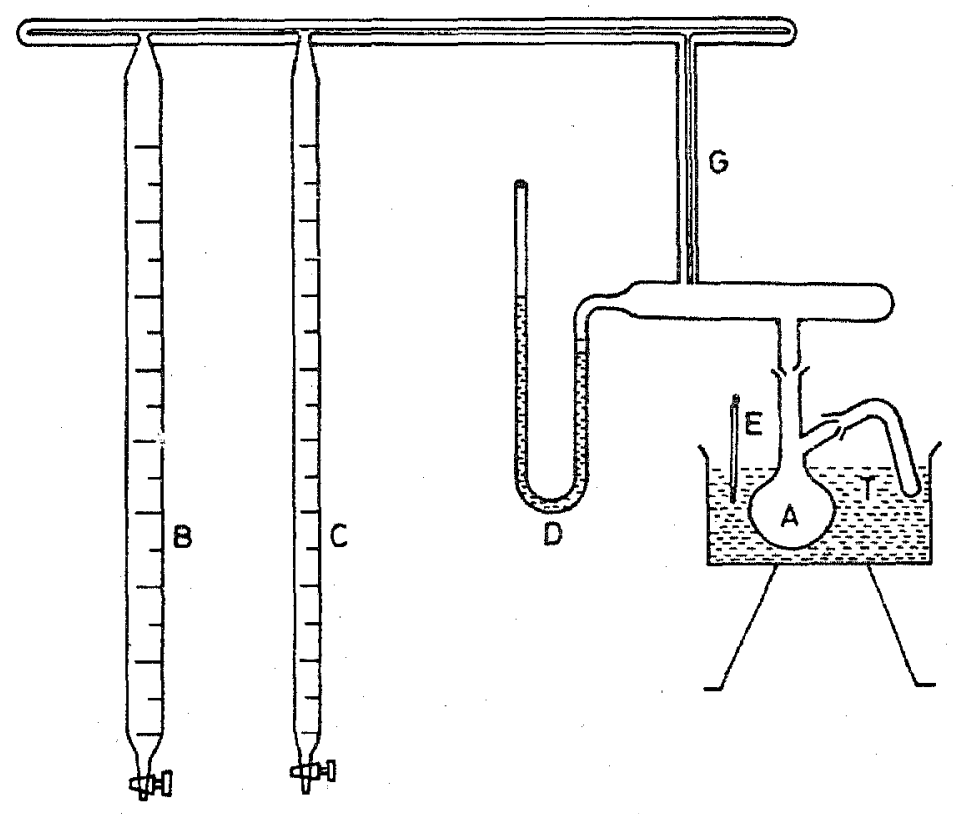

Figure 1. Experimental set-up for the determination of catalytic activity of $\mathrm{H}_{2} \mathrm{O}_{2}$ decomposition: A-reaction vessel; B-50 ml burette; $\mathrm{C}-10 \mathrm{ml}$ burette; $\mathrm{D}$-manometer; E-thermometer; T-thermostat; G-capillary tube. 
poured into the reaction vessel by rotating the ' $\mathrm{V}$ ' tube through $90^{\circ}$. A stop watch was simultaneously started to monitor the time. The entire mixture was stirred, using a magnetic stirrer, during the course of the reaction. At regular intervals of time, the burette readings were noted which indirectly measured the volume of $\mathrm{O}_{2}$ evolved in terms of the rise of manometric liquid. In the case of ferrites, $10 \mathrm{mg}$ of the sample were taken whereas in the case of cobaltites $5 \mathrm{mg}$ of the sample were sufficient to study the reaction kinetics. (With $10 \mathrm{mg}$ of cobaltites, the amount of $\mathrm{O}_{2}$ evolved was so large and rapid that, in a fraction of a second the manometric liquid flew out; thus hindering proper measurements.)

\section{Results and discussion}

The characterization and particulate properties of ferrites and cobaltites are summarized in table 1 . The XRD data clearly show that the oxides have a spinel structure and the observed $a$ values correspond to those reported in the literature. The crystallite sizes calculated from X-ray line broadening using Debye-Scherrer formula (Klug and Alexander 1954) are in the range of 6-24 nm. The particle size and surface area values range from $0.8-4.6 \mu$ and $12-140 \mathrm{~m}^{2} / \mathrm{g}$, respectively, and clearly show that the particles are very fine and therefore can be expected to be highly reactive. In fact the reactivity of these fine particles was seen in the ability of ferrite powders to achieve almost theoretical density when sintered $\sim 1000^{\circ} \mathrm{C}$. However, the large surface area of these oxide materials can be expected to find application in heterogeneous catalytic reactions, and as a test, the kinetics of $\mathrm{H}_{2} \mathrm{O}_{2}$ decomposition has been investigated. As the oxides were ultrafine in nature, the kinetics of $\mathrm{H}_{2} \mathrm{O}_{2}$ decomposition could not be studied using the $\mathrm{KMnO}_{4}$ titrimetric method (Keating et al 1965) because of the difficulty in the separation of the dispersed fine ferrite particles in $\mathrm{H}_{2} \mathrm{O}_{2}$.

The plots of volume of oxygen $V(\mathrm{ml})$ evolved versus time $t(\mathrm{~min})$ for $\mathrm{H}_{2} \mathrm{O}_{2}$ $(30 \%)$ decomposition in the presence of ferrite and cobaltite are shown in figures $2 \mathrm{a} \& \mathrm{~b}$, respectively. The specific rate constants $K_{s} \mathrm{moll}^{-1} \mathrm{~s}^{-1} \mathrm{gm}^{-1}$ with $\pm 5 \%$
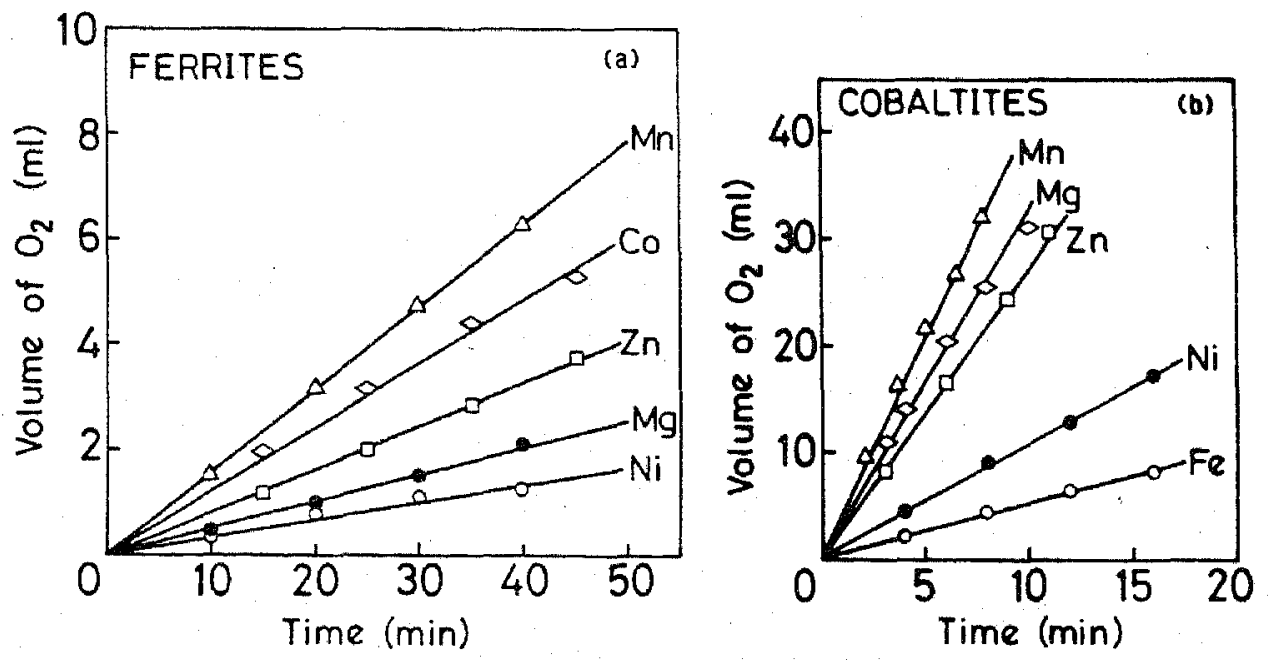

Figure 2. Decomposition of $\mathrm{H}_{2} \mathrm{O}_{2}(30 \%)$ on (a) ferrites, (b) cobaltites, at $30^{\circ} \mathrm{C}$. 
Table 2. Rate constants for $\mathrm{H}_{2} \mathrm{O}_{2}$ decomposition on ferrites and cobaltites.

\begin{tabular}{lcc}
\hline Catalysts & $\begin{array}{c}\text { Zero-order rate constants } \\
K_{s}\left(\mathrm{~mol} \mathrm{l}^{-1} \mathrm{~s}^{-1} \mathrm{gm}^{-1}\right) \text { at } 30^{\circ} \mathrm{C}\end{array}$ & $\begin{array}{c}\text { First-order rate constants } \\
K_{s}\left(\mathrm{~s}^{-1} \mathrm{gm}^{-1}\right) \text { at } 30^{\circ} \mathrm{C}\end{array}$ \\
\hline $\mathrm{MnFe}_{2} \mathrm{O}_{4}$ & 0.259 & 0.2612 \\
$\mathrm{CoFe}_{2} \mathrm{O}_{4}$ & 0.196 & 0.2316 \\
$\mathrm{NiFe}_{2} \mathrm{O}_{4}$ & 0.053 & - \\
$\mathrm{ZnFe}_{2} \mathrm{O}_{4}$ & 0.139 & - \\
$\mathrm{MgFe}_{2} \mathrm{O}_{4}$ & 0.074 & 0.0676 \\
$\mathrm{Fe}_{3} \mathrm{O}_{4}$ & 0.0268 & - \\
$\mathrm{MnCo}_{2} \mathrm{O}_{4}$ & & 0.33 \\
$\mathrm{FeCO}_{2} \mathrm{O}_{4}$ & 6.57 & - \\
$\mathrm{NiCo}_{2} \mathrm{O}_{4}$ & 0.854 & - \\
$\mathrm{ZnCo}_{2} \mathrm{O}_{4}$ & 1.784 & 0.2288 \\
$\mathrm{MgCO}_{2} \mathrm{O}_{4}$ & 4.49 & 0.632 \\
$\mathrm{Co}_{3} \mathrm{O}_{4}$ & 5.36 & - \\
\hline
\end{tabular}

error, corrected for self-decomposition of $\mathrm{H}_{2} \mathrm{O}_{2}(30 \%)$ i.e. a blank run without the catalyst $\left(\mathrm{O}_{2}\right.$ evolution rate at $\left.30^{\circ} \mathrm{C} 1.6 \times 10^{-4} \mathrm{ml} \mathrm{s}^{-1}\right)$ are given in table 2 . A linear $V-t$ plot is indicative of reaction kinetics which are zero order with respect to $\mathrm{H}_{2} \mathrm{O}_{2}$.

In the second set the decomposition kinetics with $0.3 \% \mathrm{H}_{2} \mathrm{O}_{2}$ was found to follow a rate law which was first order with respect to $\mathrm{H}_{2} \mathrm{O}_{2}$. The results are shown in figures $3 \mathrm{a}$ and $3 \mathrm{~b}$, expressed in the form of a $\log V_{\max }-V_{0} / V_{\max }-V_{t}$ versus time (min) plot, where $V_{0}$ is the volume of oxygen evolved at time $t=0, V_{\max }$ is the maximum volume of oxygen evolved at time $(t)$ gave linear plots. The specific rate constants $K_{s} \mathrm{~s}^{-1} \mathrm{gm}^{-1}$ ( $\pm 5 \%$ error, corrected for self-decomposition of $\mathrm{H}_{2} \mathrm{O}_{2}$ ) are given in table 2 . The reaction rate was monitored in the initial kinetic region,
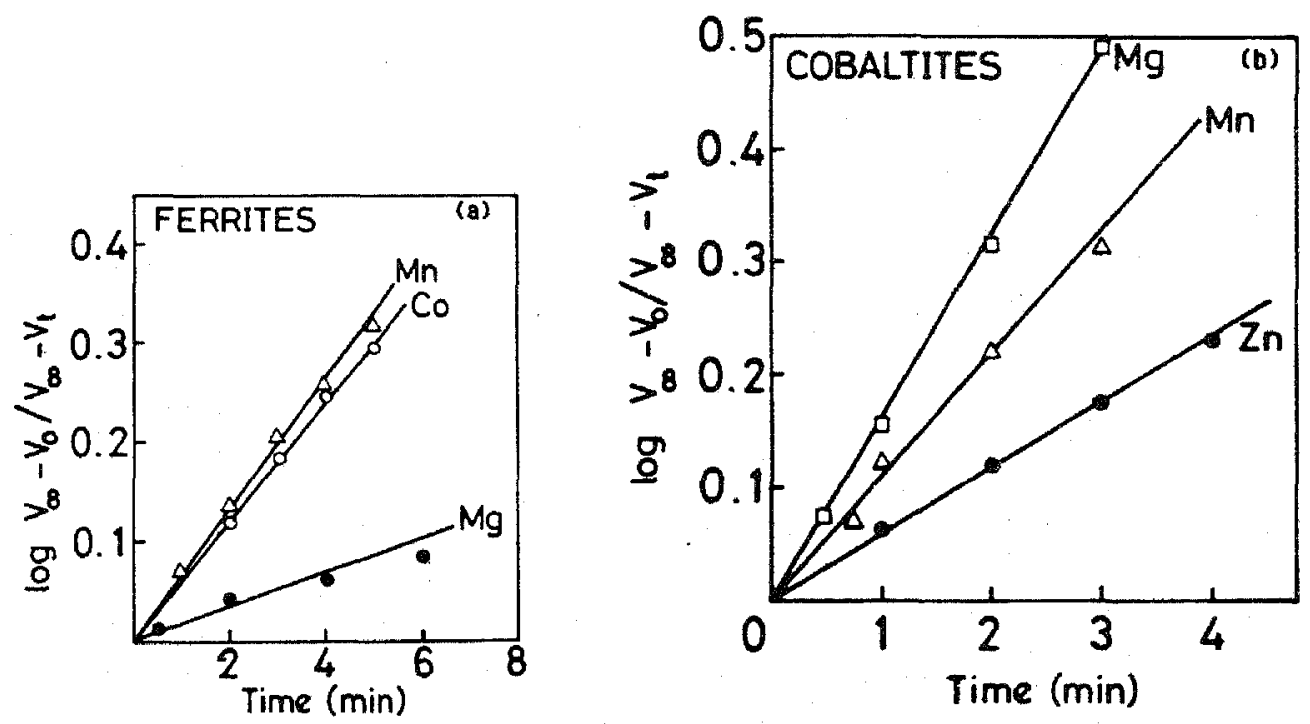

Figure 3. Decomposition of $\mathrm{H}_{2} \mathrm{O}_{2}(0-3 \%)$ on (a) ferrites, (b) cobaltites, at $30^{\circ} \mathrm{C}$. 
Table 3. Activation energies for ferrites and cobaltites.

\begin{tabular}{lcccc}
\hline & \multicolumn{3}{c}{ Rate constant $K^{\circ} \mathrm{s}^{-1} \mathrm{~g}^{-1}$} & \\
\cline { 2 - 3 } Catalyst & $K\left(308^{\circ} \mathrm{K}\right)$ & $K\left(313^{\circ} \mathrm{K}\right)$ & $K\left(318^{\circ} \mathrm{K}\right)$ & \\
\hline Ferrites & & & & \\
$\mathrm{MgFe}_{2} \mathrm{O}_{4}$ & 0.056 & 0.099 & 0.120 & 9.15 \\
$\mathrm{MnFe}_{2} \mathrm{O}_{4}$ & 0.384 & 0.673 & 0.741 & 12.32 \\
$\mathrm{CoFe}_{2} \mathrm{O}_{4}$ & 0.305 & 0.360 & 0.47 & 8.39 \\
$\mathrm{Cobaltites}$ & & & & \\
$\mathrm{MgCo}_{2} \mathrm{O}_{4}$ & 1.87 & 3.12 & - & 16.6 \\
$\mathrm{MnCo}_{2} \mathrm{O}_{4}$ & 1.08 & 1.3 & - & 11.04 \\
$\mathrm{FeCo}_{2} \mathrm{O}_{4}$ & 0.078 & 0.086 & 0.096 & 4.19 \\
$\mathrm{NiCo}_{2} \mathrm{O}_{4}$ & 0.066 & 0.115 & 0.187 & 19.78 \\
$\mathrm{ZnCo}_{2} \mathrm{O}_{4}$ & 0.370 & 0.545 & - & 17.03 \\
\hline
\end{tabular}

whereafter the first-order plots lose its linearity. This may be due to the formation of gas pockets in the solid catalyst which may mask the activity of potential sites as encountered earlier (Cota et al 1964). The reaction rate constants were found to be independent of the initial $\mathrm{H}_{2} \mathrm{O}_{2}$ concentration $(0 \cdot 3 \%)$ characterising the first-order kinetics.

The energy of activation for the first-order kinetics were also calculated, the values of which range from $7-19 \mathrm{kcal} \mathrm{mol}^{-1}$ as shown in table 3 .

The consequences of the reaction kinetics studied at two different concentrations: $30 \%$ and $0.3 \%$ has led to the conclusion that manganese and magnesium ferrites and cobaltites are quite promising as catalysts. The inactivity of large surface area oxides, $\mathrm{ZnFe}_{2} \mathrm{O}_{4}$ and $\mathrm{FeCO}_{2} \mathrm{O}_{4}$, at lower concentrations of $\mathrm{H}_{2} \mathrm{O}_{2}$ $(0.3 \%)$ appears to indicate that an optimum concentration of $\mathrm{H}_{2} \mathrm{O}_{2}$ is essential. This could in turn mean that the initial concentration of peroxide is also a matter of importance in governing the catalytic behaviour of the oxides.

The observed catalytic activity appears to be proportional to the surface area of the oxides. Thus a large surface area and a fine particle nature of the catalysts favour the heterogeneous decomposition of $\mathrm{H}_{2} \mathrm{O}_{2}$. However, when comparing the order of reactivity in a given set of ferrites or cobaltites with the order of surface areas, some discrepancies are observed which can be explained in terms of the electronic structure and surface morphology of the spinels, that is, the distribution of $\mathrm{M}^{2+}$ and $\mathrm{Fe}^{3+}$ or $\mathrm{Co}^{3+}$ ions in the tetrahedral or octahedral sites in the spinel. Another important feature observed is that the cobaltites, having lower surface areas, are much more active than the ferrites. This may be explained in terms of the better electron-hopping ability of $\mathrm{Co}^{2+}$ or $\mathrm{Co}^{3+}$ species in the octahedral sites of spinels. The high reactivity of the $\mathrm{MnFe}_{2} \mathrm{O}_{4}$ and $\mathrm{MnCo}_{2} \mathrm{O}_{4}$ could also be speculated upon in similar terms. The redox couple $\left[\mathrm{Mn}^{2+}-\mathrm{Fe}^{3+}\right]$ and $\left[\mathrm{Mn}^{2+}-\mathrm{Co}^{3+}\right]$ appear to have even greater potentiality than

$$
\left[\mathrm{Co}^{2+}-\mathrm{Co}^{3+}\right]_{\mathrm{oct}}>\left[\mathrm{Co}^{2+}-\mathrm{Fe}^{3+}\right]_{\mathrm{oct}}>\left[\mathrm{Co}^{2+}\right]_{\mathrm{tet}} \gg\left[\mathrm{Fe}^{2+}-\mathrm{Fe}^{3+}\right]_{\mathrm{oct}}>\left[\mathrm{Fe}^{2+}\right]_{\mathrm{tet}}
$$

reported earlier (Goldstein and Tseung 1974).

Since most catalytic decompositions of $\mathrm{H}_{2} \mathrm{O}_{2}$ have been studied in the presence of $\mathrm{KOH}$, which is known to control the reaction kinetics, a representative 
experiment was done with $\mathrm{CoFe}_{2} \mathrm{O}_{4}$ using $\mathrm{KOH}$. The observed rate constant $\left(K=0.4545 \mathrm{~s}^{-1} \mathrm{~g}^{-1}\right)$ is much higher than the value reported earlier $\left(K=0.120 \mathrm{~s}^{-1} \mathrm{~g}^{-1}\right.$ ) (Goldstein and Tseung 1974). This suggests that the fine particle ferrites and cobaltites prepared by the low temperature precursor technique have better catalytic activity than conventional oxides.

\section{References}

Cota H M, Katan J, Chim M and Schoenweis F J 1964 Nature (London) 2031281

Deren J, Haber J, Padgorechka and Burzyk J 1963 J. Catal. 2161

Goldstein J R and Tseung A C C 1974 J. Catal. 32452

Keating K B, Rozner A G and Youngblood J L 1965 J. Catal. 4608

Klug H P and Alexander L E $1954 X$-ray diffraction procedures (New York : John Wiley \& Sons) chap. 8, p. 566

Onuchukwu A I $1984 \mathrm{~J}$. Chem. Soc. Faraday Trans. I 801447

Ravindranathan P, Mahesh G V and Patil K C 1987 J. Solid State Chem. 6620

Ravindranathan P and Patil K C 1987 Am. Ceram. Soc. Bull. 66688

Schumb W C, Satterfield C N and Wentworth R L 1955 Hydrogen peroxide (New York : Reinhold) chap. 8 , p. 472

Tarasevich M R and Efremov B N 1980 in Electrodes of conductive metallic oxides (ed.) S Trasatti (Amsterdam: Elsevier Scientific Publishing Company) vol. 11, part A, p. 250 